\title{
PENDUGAAN DAERAH PENANGKAPAN IKAN LAYANG DENGAN CITRA SATELIT DI PERAIRAN ACEH SEKITAR PIDIE JAYA
}

\section{ESTIMATION FISHING GROUND OF SCADS WITH SATELLITE IMAGE IN ACEH WATER AROUND PIDIE JAYA}

\author{
Afdhal Fuadi ${ }^{1}$, Budy Wiryawan ${ }^{2}$, Mustaruddin $^{2}$ \\ ${ }^{1}$ Program Studi Teknologi Perikanan Laut, \\ ${ }^{2}$ Departemen Pemanfaatan Sumberdaya Perikanan, \\ Fakultas Perikanan dan Ilmu Kelautan, Institut Pertanian Bogor \\ Korespondensi : afdhal_fuadi@apps.ipb.ac.id
}

\begin{abstract}
The fishing ground of fish Scads always in a state of change and move in a way following the changes in environmental conditions that naturally fish would choose a more suitable habitat. Fishermen in Pidie Jaya determine fishing grounds only by looking at natural signs, learned from generation to generation, so this method is less effective in fishing ground. The use of satellite remote sensing have been shown to play a key role in the study of Oceanography fisheries for predicting the fishing area. This research aimed to determine the amount of the catch and to measure fish length, to specify the spread of chlorophyll-a and SST. The fishing ground map was created to prediction potential distribution around Pidie Jaya. The method used in this study is survey was following directly into the fishing area and interviewing the mini purse seine ship captain. The concentration of chlorophyll-a in the location of fisheries during the study ranged from $0,13-0,85 \mathrm{mg} / \mathrm{m}^{3}$ and an average $0,35 \mathrm{mg} / \mathrm{m}^{3}$, while the temperature of the sea surface with an average value of $29,25^{\circ} \mathrm{C}$. Scads fish length caught during the months of September through November ranged from 17,9-21,9 $\mathrm{cm}$ long with an average that is $19,7 \mathrm{~cm}$. The potensial of Scad fishing ground off the coast of a fish landing base (PPI) to the fisheries is $>6$ nautical miles offshore.
\end{abstract}

Keyword: Aceh, fishing ground of fish scad, Pidie Jaya, satellite image

\begin{abstract}
ABSTRAK
Daerah penangkapan ikan layang selalu dalam keadaan berubah dan berpindah tempat dengan cara mengikuti perubahan kondisi lingkungan yang secara alamiah ikan akan memilih habitat yang lebih sesuai. Nelayan Pidie Jaya dalam menentukan daerah penangkapan ikan hanya dengan cara melihat tanda-tanda alam yang dipelajari secara turun temurun, sehingga dengan cara tersebut kurang efektif dalam usaha penangkapan ikan. Penggunaan satelit remote sensing telah terbukti memainkan peran kunci dalam pengkajian oseanografi perikanan untuk memprediksi daerah penangkapan ikan. Penelitian ini bertujuan untuk menentukan jumlah hasil tangkapan dan ukuran panjang ikan layang, menentukan penyebaran klorofil-a dan suhu permukaan laut. Membuat peta pendugaan daerah penangkapan ikan layang potensial di perairan Aceh sekitar Pidie Jaya. Metode yang digunakan dalam penelitian ini adalah metode survei dengan cara mengikuti langsung ke daerah penangkapan ikan dan wawancara terhadap nahkoda kapal mini purse seine. Konsentrasi kandungan klorofil-a di lokasi penangkapan ikan selama penelitian berkisar antara 0,13-0,85 $\mathrm{mg} / \mathrm{m}^{3} \mathrm{dan}$ rata-rata $0,35 \mathrm{mg} / \mathrm{m}^{3}$, sedangkan suhu permukaan laut dengan nilai rata-rata $29,25^{\circ} \mathrm{C}$. Ukuran panjang ikan layang yang tertangkap selama bulan September sampai November berkisar antara 17,9-21,9 cm dengan panjang rata-rata yaitu 19,7 $\mathrm{cm}$. Daerah penangkapan ikan layang potensial berada pada laut lepas pantai yang berjarak dari Pangkalan Pendaratan Ikan (PPI) ke daerah penangkapan ikan > 6 mil laut.
\end{abstract}

Kata kunci: Aceh, citra satelit, daerah penangkapan ikan layang, Pidie Jaya 


\section{PENDAHULUAN}

Perikanan merupakan salah satu bidang usaha yang diharapkan mampu membuat kesejahteraan nelayan di Aceh, sub sektor perikanan dapat berperan dalam pemulihan dan pertumbuhan perekonomian bangsa Indonesia karena potensi sumberdaya ikan yang besar dalam jumlah dan keragamannya (Rahmawati et al. 2013). Letak geografis provinsi Aceh pada koordinat 20-60 Lintang Utara dan 950-980 Bujur Timur, sedangkan luas laut perairan Aceh $295.370 \mathrm{~km}^{2}$ yang terdiri atas perairan kepulauan seluas $56.563 \mathrm{~km}^{2}$ dan Zona Ekonomi Eksklusif (ZEE) 238.807 km² (Rizwan et al. 2011).

Kabupaten Pidie Jaya adalah salah satu wilayah yang terdapat di provinsi Aceh yang terletak pada koordinat 4054'16"5018'03" Lintang Utara dan 9601'14"96022'01" Bujur Timur. Menurut Fuadi et al. (2016), hasil tangkapan ikan pelagis kecil pada bulan Februari dan Maret 2016 (Musim peralihat Barat-Timur) yang di daratkan di PPI Meureudu sebanyak 35.258 kg yang terdiri dari 4 spesies diantaranya adalah ikan layang (Decapterus spp) paling banyak tertangkap dengan alat tangkap purse seine.

Perairan Indonesia terdapat 5 jenis ikan layang yang umum yakni Decapterus kurroides, Decapterus russelli, Decapterus macrosoma, Decapterus layang, dan Decapterus maruadsi (Sarumaha et al. 2016). Menurut Febri (2012); Fuadi et al. (2016) ikan layang yang tertangkap di perairan Aceh ada dua spesies, yakni Decapterus russelli dan Decapterus macrosoma yang merupakan salah satu ikan terpenting dari sumber daya perikanan pelagis kecil di perairan Aceh terutama di kabupaten Pidie Jaya dan mempunyai nilai ekonomis penting, sehingga banyak dicari dan ditangkap oleh armada pukat cicin (purse seine) sebagai target utama dalam usaha penangkapan ikan.

Daerah penangkapan ikan khususnya untuk kelompok ikan pelagis dan salah satunya adalah ikan layang selalu dalam keadaan berubah dan berpindah tempat dengan cara mengikuti perubahan kondisi lingkungan yang secara alamiah ikan akan memilih habitat yang lebih sesuai untuk kehidupan dan pertumbuhannya (Gaol et al. 2004). Habitat ikan tersebut sangat dipengaruhi oleh parameter oseanografi seperti suhu permukaan laut, konsentrasi klorofil-a, dan kedalaman perairan (Laevastu \& Hayes 1981; Gunarso
1985; Simbolon et al. 2009; Tangke et al. 2016).

Nelayan Pidie Jaya dalam melakukan kegiatan penangkapan ikan dengan cara mencari posisi daerah penangkapan dengan melihat tanda-tanda alam, seperti segerombolan burung yang ada di permukaan, adanya gelembung-gelembung yang muncul ke permukaan dan dengan cara melihat bintang di waktu malam hari. Sehingga dengan cara tersebut nelayan akan membutuhkan waktu yang lama dan akan mengakibatkan kebutuhan penangkapan ikan meningkat.

Menurut Muklis et al. (2009); Suhartono et al. (2013); Fuadi et al. (2016), salah satu faktor keberhasilan dalam menentukan suatu daerah penangkapan ikan salah satunya adalah ikan layang dengan cara ketepatan dalam menduga fishing ground. Hal ini juga senada dengan Febri (2012)yang menyatakan bahwa nelayan di Aceh pada umumnya dalam melakukan penangkapan ikan masih berdasarkan pada fenomena alam yang dipelajari secara turun temurun (tradisional) dan juga pengalaman dalam melaut.

Dalam upaya mengoptimalkan pemanfaatan sumberdaya ikan khususnya untuk ikan layang diperlukan berbagai informasi mengenai kondisi parameter oseanografi yang berkaitan erat dengan daerah penangkapan ikan tersebut (Laevastu \& Hela 1970; Royce 1984). Salah satu cara untuk dapat memahami suatu dinamika lingkungan laut, termasuk mengetahui perubahan ketersediaan sumber daya ikan dan daerah penangkapannya saat ini telah dikembangkan teknologi penginderaan jauh dengan satelit dalam bidang perikanan untuk membantu menyediakan database dalam bidang oseanografi perikanan misalnya untuk prediksi daerah penangkapan ikan (Zainuddin et al. 2006; Mugo et al. 2010).

Menurut Safruddin et al. (2013), pola kehidupan ikan layang tidak bisa dipisahkan dari adanya berbagai kondisi oseanografi seperti suhu permukaan laut, salinitas, konsentrasi klorofil-a, cuaca serta perubahan yang akan mempengaruhi kehidupan dan pertumbuhan ikan. Hal ini berarti bahwa perubahan parameter oseanografi akan berpengaruh terhadap keberadaan ikan dan pembentukan daerah penangkapan ikan layang di suatu perairan (Basuma 2009).

Penggunaan satelit remote sensing telah terbukti memainkan peran kunci dalam pengkajian oseanografi perikanan 
untuk memprediksi daerah penangkapan ikan (Polovina et al. 2001; Zainuddin et al. 2006; Zainuddin et al. 2015). Menurut Semedi dan Dimyati (2009) menunjukkan adanya hubungan antara suhu permukaan laut dan klorofil-a melalui pengamatan dengan citra satelit Aqua-MODIS terhadap keberadaan ikan di suatu perairan.

Kombinasi penginderaan jauh ini diharapkan dapat memberikan dukungan informasi kepada stakeholders tentang prediksi daerah penangkapan ikan layang secara tepat waktu dan berkesinambungan untuk pengembangan ekonomi nelayan (Safruddin 2013). Berdasarkan adanya hubungan parameter suhu permukaan laut dan klorofil-a terhadap keberadaan ikan layang di perairan, maka dapat diperkirakan daerah penangkapan ikan layang yang layak tangkap dengan cara menganalisis parameter klorofil-a, suhu permukaan laut dan ukuran panjang ikan layang, setelah itu akan dibuat dalam bentuk peta daerah penangkapan ikan layang di perairan Aceh sekitaran Pidie Jaya.

\section{METODE PENELITIAN}

\section{Waktu dan lokasi penelitian}

Penelitian ini dilaksanakan pada bulan September sampai dengan bulan November 2018 dan dilakukan dengan 2 tahap, tahap pertama yaitu pengambilan data hasil tangkapan dan pengukuran panjang ikan layang yang akan dilakukan di Pangkalan Pendaratan Ikan (PPI) Meureudu, untuk pengumpulan data lapangan dilakukan pada bulan September sampai bulan November 2018 (Musim Peralihan Timur-Barat), kemudian tahap kedua yaitu pengolahan data citra satelit kandungan klorofil-a dan suhu permukaan laut yang akan dilakukan pada bulan November 2018 di Laboratorium DPI FPIK IPB Bogor. Peta lokasi penelitian dapat di lihat pada Gambar 1.

\section{Metode pengumpulan data}

Metode yang digunakan dalam penelitian ini adalah metode survei dengan melakukan pengamatan terhadap armada atau unit penangkapan ikan layang. Data yang dibutuhkan dalam penelitian ini adalah data primer (data lapangan) dan data sekunder (data citra satelit).

Pengumpulan data primer dilakukan dengan mengikuti langsung aktivitas armada penangkapan ikan layang. Armada penangkapan yang digunakan dalam pengamatan data primer adalah alat tangkap mini purse seine, karena alat tangkap tersebut yang paling banyak digunakan oleh nelayan di Pangkalan Pendaratan Ikan (PPI) Meureudu dan dominan menangkap ikan layang.

Penentuan armada penangkapan dan nelayan responden dalam penelitian ini dengan sengaja atau purposive sampling yaitu, menggunakan armada penangkapan mini purse seine yang berukuran antara 5 sampai 10 Gross Tonnage (GT), karena ukuran kapal tersebut sudah menggunakan alat GPS. Jumlah kapal di PPI Meureudu sebanyak empat unit dari ukuran 5 sampai 10 GT dan kapal tersebut akan dijadikan sebagai objek pengambilan data dalam penelitian ini.

Data yang dikumpulkan dari setiap armada kapal mini purse seine adalah pencatatan daerah dan waktu penangkapan ikan, jumlah hasil tangkapan, dan ukuran panjang ikan layang. Pengambilan sampel ikan layang untuk di ukur panjang dilakukan secara acak sederhana (simple random sampling) terhadap sampel untuk pengukuran panjang ikan sejumlah 10\% dari total hasil tangkapan (Azwar \& Saifuddin 2010; Liestina et al. 2015).

Data sebaran suhu permukaan laut dan klorofil-a merupakan data sekunder yang diperoleh melalui dengan cara mendownload dari citra satelit yang telah tersedia di internet dan bisa diperoleh dengan cara gratis, data di-download dari situs resmi NASA Aqua-MODIS http://oceancolor.gsfc. nasa.gov. Pengambilan data citra AquaMODIS level 3 terbagi kedalam dua jenis, yaitu; (1) data citra satelit bulanan yaitu bulan September sampai November 2018 yang disesuaikan dengan waktu dan lokasi pengamatan daerah penangkapan ikan layang di lapangan, (2) pemilihan citra suhu permukaan laut dan klorofil-a yang bebas dari awan, kemudian akan diolah dan dioutput dalam bentuk format JPEG.

\section{Analisis data}

Hasil tangkapan ikan layang yang diperoleh kemudian dikelompokkan berdasarkan jumlah hasil tangkapan dan unit penangkapan di perairan Aceh sekitar Pidie Jaya. Jumlah hasil tangkapan ikan layang per upaya penangkapan Catch Per Unit Effort (CPUE) dihitung secara temporal dan 
spasial (Gulland 1983; Petrere et al. 2010). Selanjutnya dicari jumlah hasil tangkapan ikan layang per upaya penangkapan nilai CPUE (Catch Per Unit Effort) dibuat dalam periode waktu mingguan.

Pengukuran panjang hasil tangkapan ikan layang sangat berpengaruh terhadap tingkat keramahan lingkungan yang dilihat dari segi perbandingan panjang total (TL) terhadap Length at first maturity (Lm), hal tersebut merupakan bagian yang penting terhadap penentuan suatu daerah penangkapan ikan potensial di suatu perairan. Perbandingan panjang total (TL) terhadap Length at first maturity (Lm) digunakan untuk mengetahui hasil tangkapan ikan layang yang diperoleh termasuk ke dalam kategori layak tangkap atau tidak layak tangkap. Data Lm untuk spesies ikan layang diperoleh dari www. fishbase.org.

Data sebaran suhu permukaan laut dan klorofil-a diketahui dari citra satelit Aqua-MODIS dan diolah dengan software SeaDAS (Sea Data Analysis System), kemudian diolah lagi dengan software ArcGIS 10.3 untuk pembuatan peta daerah potensial penangkapan ikan layang. Konsentrasi klorofil-a dan suhu permukaan laut pada daerah penangkapan ikan saat trip operasi penangkapan dapat dihitung dengan menggunakan software SeaDas 7.3. Citra klorofil-a dan suhu permukaan laut kemudian diolah untuk mendapatkan konsentrasi berdasarkan secara temporal dan posisi daerah penangkapan ikan layang (spasial), untuk memperbaiki tampilan citra terdapat beberapa program atau fungsi dalam proyeksi analisis pada citra satelit (SeaDas).

Guna untuk mengetahui pengaruh antara klorofil-a dan suhu permukaan laut terhadap hasil tangkapan ikan layang, maka dilakukan analisis regresi linier sederhana dengan formula $Y=a+b X$ (Walpole 1995). Keeratan hubungan antara suhu permukaan laut dan klorofil-a terhadap hasil tangkapan ikan layang diketahui berdasarkan nilai koefisien korelasi (r). Nilai koefisien korelasi berkisar antara (-1) sampai (1) dengan tingkat kepercayaan yang digunakan adalah 95\% (Sarwono 2008).

\section{Pendugaan daerah potensial penangkapan ikan layang}

Indikator daerah potensial penangkapan ikan layang yang diteliti adalah hasil tangkapan ikan layang, ukuran panjang ikan layang, sebaran suhu permukaan laut dan klorofil-a di suatu daerah penangkapan ikan. Masing-masing indikator tersebut dievaluasi secara parsial dan diberi nilai (score), kemudian hasil evaluasi tersebut dapat digunakan untuk pendugaan daerah penangkapan ikan layang potensial di perairan Aceh sekitar Pidie Jaya.

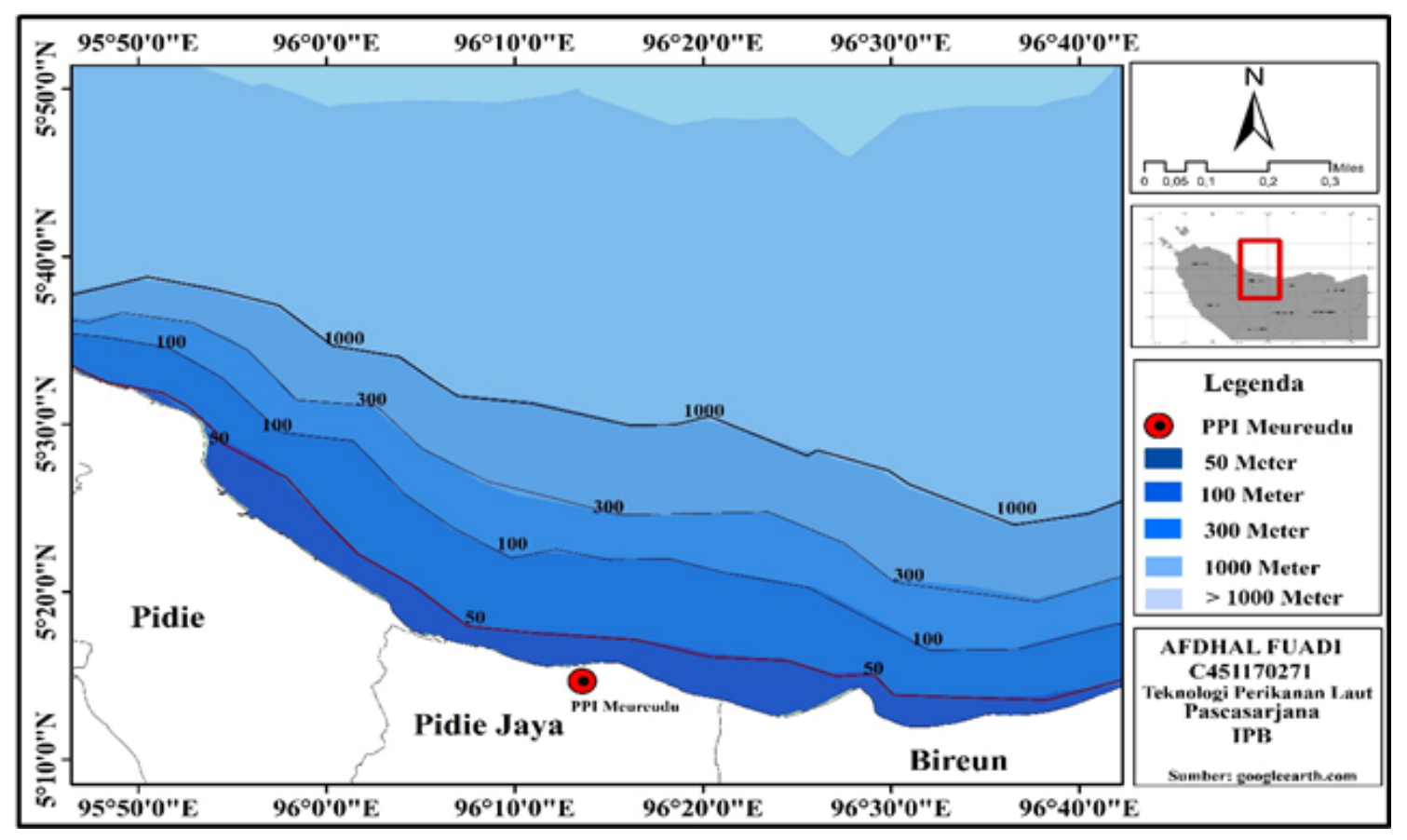

Gambar 1. Peta lokasi penelitian (googleearth.com) 
Penentuan daerah penangkapan ikan layang potensial berdasarkan indikator hasil tangkapan ikan layang dengan cara melihat nilai CPUE tertinggi dan terendah selama penelitian. Jika nilai CPUE berada dalam kelas tangkapan tertinggi lebih besar dari nilai CPUE rata-rata, maka diberi skor 2 dan dikategorikan tinggi, kemudian jika nilai CPUE berada dalam kelas tangkapan terendah lebih kecil dari nilai CPUE ratarata, maka diberi skor 1 dan dikategorikan rendah.

Penentuan daerah penangkapan ikan layang juga bisa diukur dengan indikator ukuran panjang ikan layang dilakukan dengan membandingkan panjang rata-rata ikan layang (TL) terhadap Length at first maturity (Lm). Setelah dilakukan perbandingan antara rata-rata panjang ikan layang selanjutnya dapat ditentukan daerah potensial penangkapan ikan layang yang termasuk ke dalam kategori layak tangkap atau kategori tidak layak tangkap. Jika ukuran panjang ikan layang $>16 \mathrm{~cm}$ dikategorikan layak tangkap kemudian diberi skor 2 dan jika ukuran ikan layang $<16 \mathrm{~cm}$ dikategorikan tidak layak tangkap kemudian diberi skor 1 .

\section{Suhu Permukaan Laut (SPL)}

Suhu permukaan laut dapat berpengaruh terhadap penyebaran atau keberadaan ikan layang di suatu perairan. Menurut Baskoro et al. (2004), suhu dapat mempengaruhi penyebaran keberadaan ikan, dikarenakan (1) sebagai pengatur proses metabolisme dalam tubuh (dapat mempengaruhi permintaan kebutuhan makanan dan tingkat penerimaan serta tingkat pertumbuhan), (2) sebagai pengatur aktivitas pergerakan tubuh (kecepatan renang), dan (3) sebagai stimulus syaraf. Jika $\mathrm{SPL}>28,00$ sampai $30,00{ }^{\circ} \mathrm{C}$ dikategorikan optimum kemudian diberi skor 2 dan jika $\mathrm{SPL}<28,00$ dan $>30,00{ }^{\circ} \mathrm{C}$ dikategorikan tidak optimum kemudian diberi skor 1 .

\section{Klorofil-a}

Nilai klorofil-a optimum dapat berpengaruh secara signifikan terhadap hasil tangkapan ikan layang. Menurut Muklis et al. (2009); Prastianto (2016), meningkatnya konsentrasi klorofil-a di suatu perairan berpengaruh dan terdapat hasil tangkapan yang meningkat, begitu sebaliknya penurunan konsentrasi klorofil-a berpengaruh dan terdapat hasil tangkapan ikan yang menurun. Jikan nilai klorofil-a > $1 \mathrm{mg} / \mathrm{m} 3$ dikategorikan tinggi kemudian diberi skor 2 dan jika $<1 \mathrm{mg} / \mathrm{m} 3$ dikategorikan rendah kemudian diberi skor 1 .

Langkah terakhir untuk dapat menentukan daerah potensial penangkapan ikan layang adalah dengan cara mengelompokkanjumlahnilaiskorgabungan yang ditentukan melalui penjumlahan nilai skor dari keempat indikator di atas. Setelah diperoleh skor masing-masing indikator kemudian dijumlahkan semua indikator tersebut.

\section{HASIL DAN PEMBAHASAN}

\section{Sebaran klorofil-a dan suhu permukaan laut}

Hasil pengamatan citra satelit sebaran kandungan klorofil-a menurut waktu dan lokasi pengamatan di daerah penangkapan ikan di perairan Aceh sekitar kabupaten Pidie Jaya dapat dilihat pada Gambar 2, terlihat bahwa konsentrasi klorofil-a di lokasi penangkapan ikan selama penelitian berkisar dari $0,13-0,85$ $\mathrm{mg} / \mathrm{m}^{3}$ dan rata-rata $0,35 \mathrm{mg} / \mathrm{m}^{3}$. Citra pada Gambar 2 terlihat bahwa semakin mendekati pantai konsentrasi klorofil-a cenderung semakin tinggi, hal ini juga senada dengan Parson et al. (1984); Febri (2012) yang menyatakan bahwa sebaran konsentrasi klorofil-a semakin tinggi ke arah pantai dikarenakan suplai nutrien yang berasal dari daratan melalui aliran air sungai.

Kandungan suhu permukaan laut di perairan Aceh sekitar Pidie Jaya pada bulan September sampai bulan November 2018 sangat bervariasi mulai dari suhu yang terendah $27,28^{\circ} \mathrm{C}$ hingga yang tertinggi yaitu $32,85^{\circ} \mathrm{C}$ dan nilai rata-rata $29,25^{\circ} \mathrm{C}$ (Gambar 3). Menurut Febri (2012); Hamka (2012); Fuadi et al. (2016), suhu permukaan laut pada musim peralihat Barat-Timur termasuk hangat berkisar antara 28,00 sampai $32,00{ }^{\circ} \mathrm{C}$ jika dibandingkan dengan suhu permukaan laut pada musim peralihan Timur-Barat berkisar antara 25,40 sampai $30,00{ }^{\circ} \mathrm{C}$. 


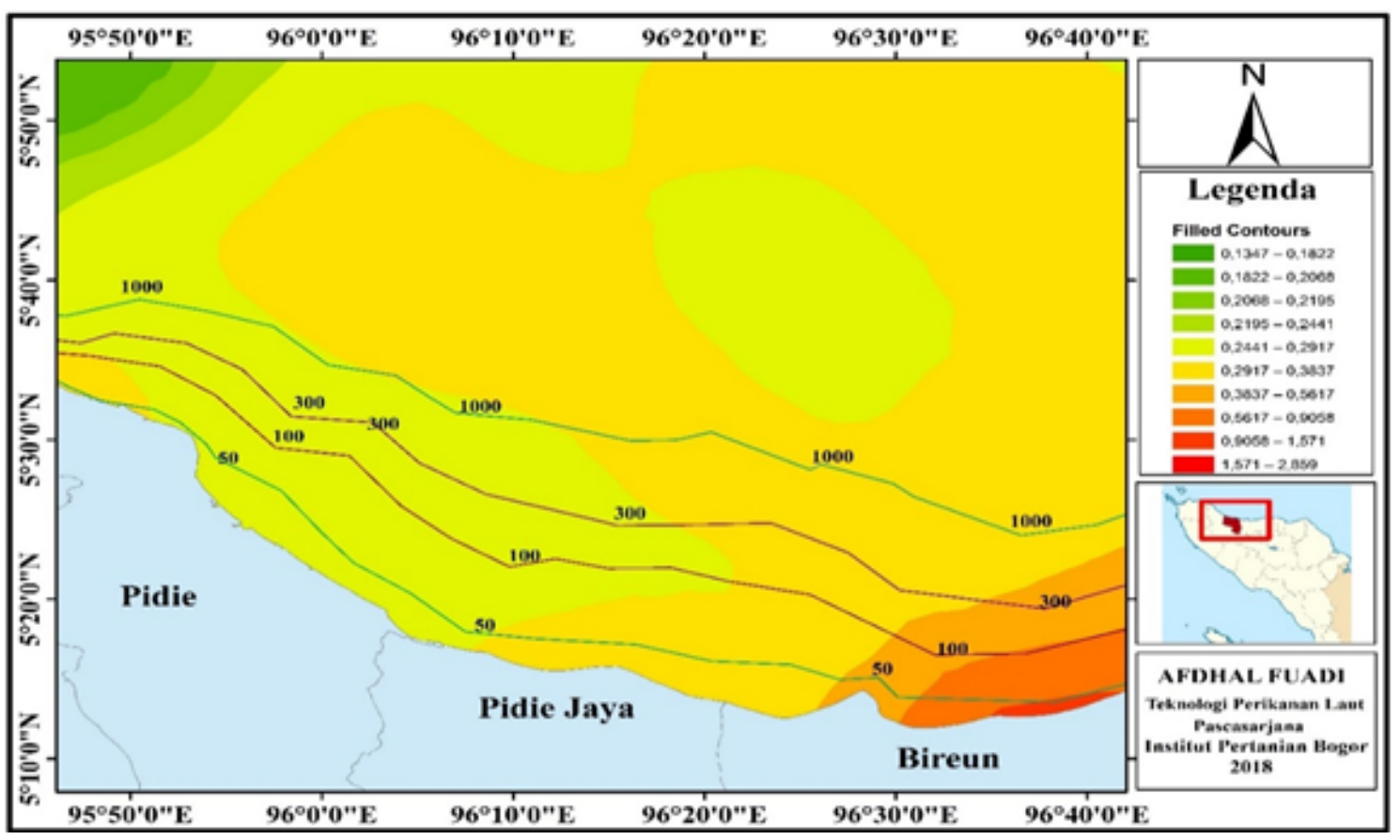

Gambar 2. Sebaran rata-rata konsentrasi klorofil-a di perairan Aceh

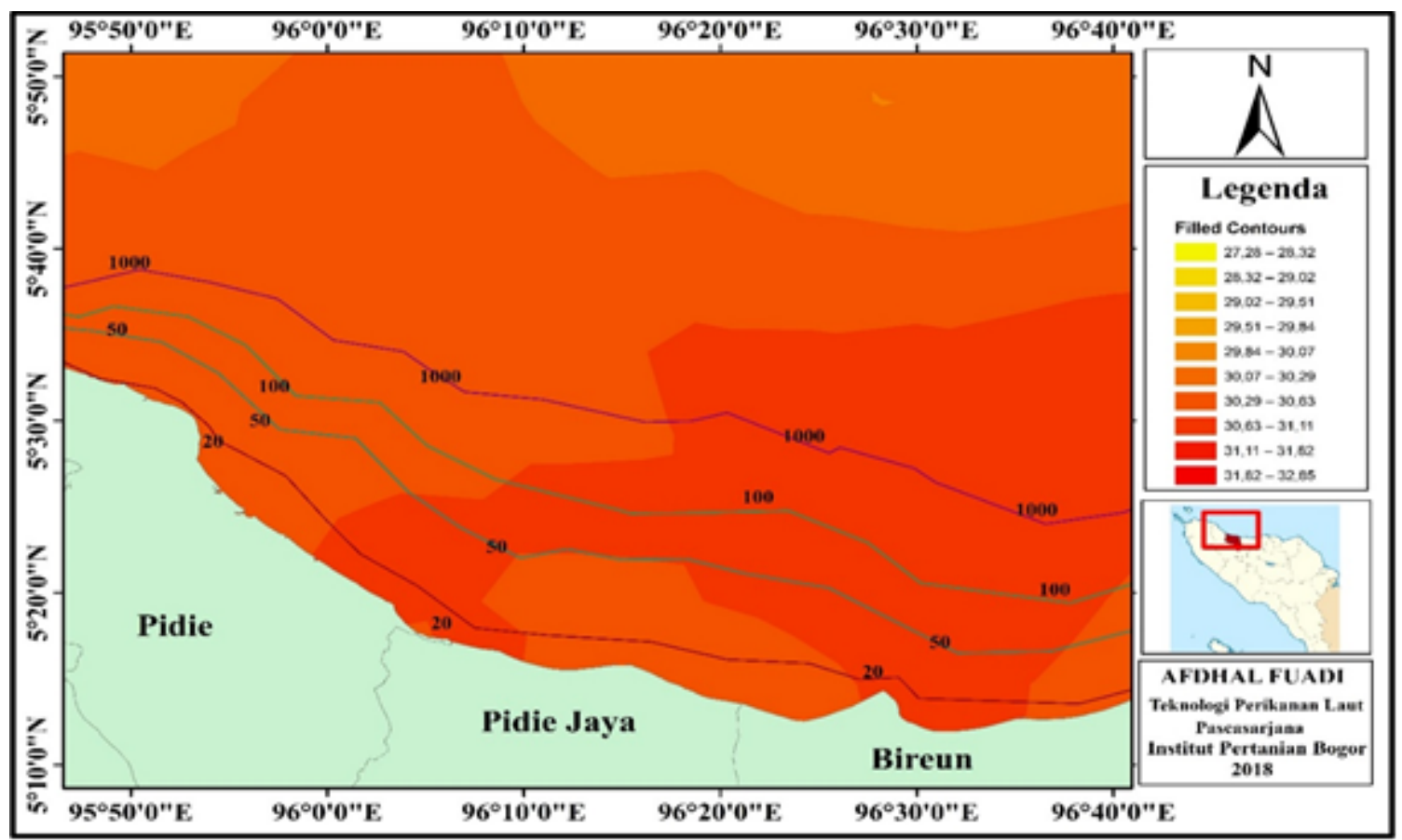

Gambar 3. Citra sebaran kandungan suhu permukaan laut di perairan Aceh sekitar Pidie Jaya

\section{Jumlah hasil tangkapan dan ukuran panjang ikan layang}

Jumlah hasil tangkapan ikan layang (Decapterus russelli) di perairan Aceh sekitar Pidie Jaya mengalami fluktuasi pada bulan September sampai dengan bulan November 2018 mencapai $89.766 \mathrm{~kg}$. Hasil tangkapan ikan layang secara temporal paling banyak tertangkap selama bulan September sampai bulan November 2018 yaitu pada tanggal 8 sampai 15 Oktober yaitu sebesar $19.816 \mathrm{~kg}$ dan paling rendah tertangkap pada tanggal 22 sampai 29 September sebanyak $3.990 \mathrm{~kg}$ (Gambar 4).

Hasil tangkapan ikan layang secara temporal yaitu pada musim peralihan Timur-Barat 2018 ini termasuk kategori 
paling banyak jika dibandingkan dengan hasil tangkapan pada musim peralihan Barat-Timur 2016 di perairan Aceh sekitar Pidie Jaya. Hasil tangkapan paling banyak tertangkap pada musim peralihan TimurBarat sebesar $89.766 \mathrm{~kg}$ sementara hasil tangkapan pada musim peralihan BaratTimur mencapai $35.258 \mathrm{~kg}$ (Fuadi et al. 2016).

\section{CPUE ikan layang}

Pola penyebaran hasil tangkapan CPUE menunjukkan pola yang bervariasi dari setiap minggunya di perairan sekitar Pidie Jaya pada periode September sampai November 2018 disajikan pada Gambar 5. Berdasarkan Gambar 5 nilai Catch per Unit Effort selama bulan September sampai dengan bulai November tertinggi terdapat pada tanggal 8 sampai 15 Oktober yaitu sebesar $2.831 \mathrm{~kg} /$ trip dan paling rendah terdapat pada tanggal 22 sampai 29 September yaitu sebesar $665 \mathrm{~kg} /$ trip.

Tingginya nilai CPUE pada tanggal 8 sampai 15 Oktober diduga karena banyaknya trip yang dilakukan oleh nelayan Pidie Jaya dan juga informasi dari nelayan yang bahwa musim puncak penangkapan ikan terjadi pada bulan Oktober. Menurut Amri (2002), masa pemijahan ikan layang pada umumnya terjadi dua kali dalam satu tahun yaitu pada bulan Maret sampai Mei (musim peralihan Barat-Timur) dan pada bulan September sampai November (musim peralihan Barat-Timur).

\section{Hubungan klorofil-a dan SPL terhadap hasil tangkapan}

Konsentrasi klorofil-a > 0,20 $\mathrm{mg} / \mathrm{m}^{3}$ telah menunjukkan kehadiran dari fitoplankton yang memadai untuk mempertahankan rantai makanan dan kelangsungan hidup untuk melakukan perkembangbiakan ikan di suatu perairan (Gower \& Apel 1972). Hubungan sebaran klorofil-a terhadap hasil tangkapan ikan layang selama musim peralihan TimurBarat menggunakan analisis regresi yang menunjukkan nilai koefisien determinasi $\left(R^{2}\right)$ adalah 0,3442 , artinya hasil tangkapan ikan layang dipengaruhi oleh peningkatan sebaran klorofil-a sebesar $34,42 \%$ dan sisanya dipengaruhi oleh faktor lain (Gambar $6)$.

Kondisi ini berarti dapat mengindikasikan adanya faktor-faktor lain yang mempengaruhi daerah penangkapan ikan layang selain konsentrasi klorofil-a terhadap dinamika pergerakan ikan layang seperti salinitas dan arus (Hamka 2012). Menurut Andrius (2007) bahwa ada empat parameter oseanografi utama yang dapat mempengaruhi ruaya (migrasi) dan sebaran (distribusi) ikan layang, diantaranya yaitu: salinitas perairan, suhu permukaan laut (SPL), kelimpahan makanan, dan arus laut.

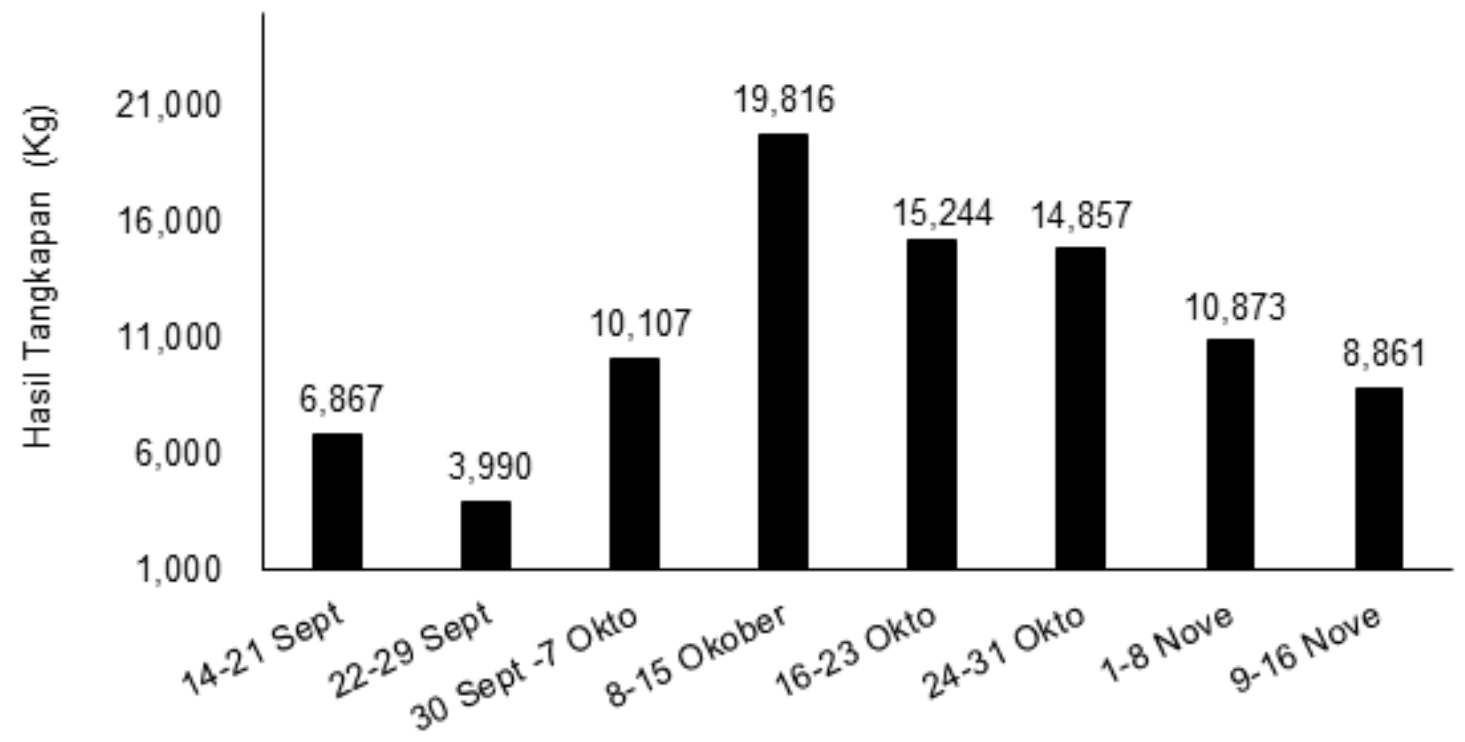

Gambar 4. Grafik jumlah hasil tangkapan ikan layang 


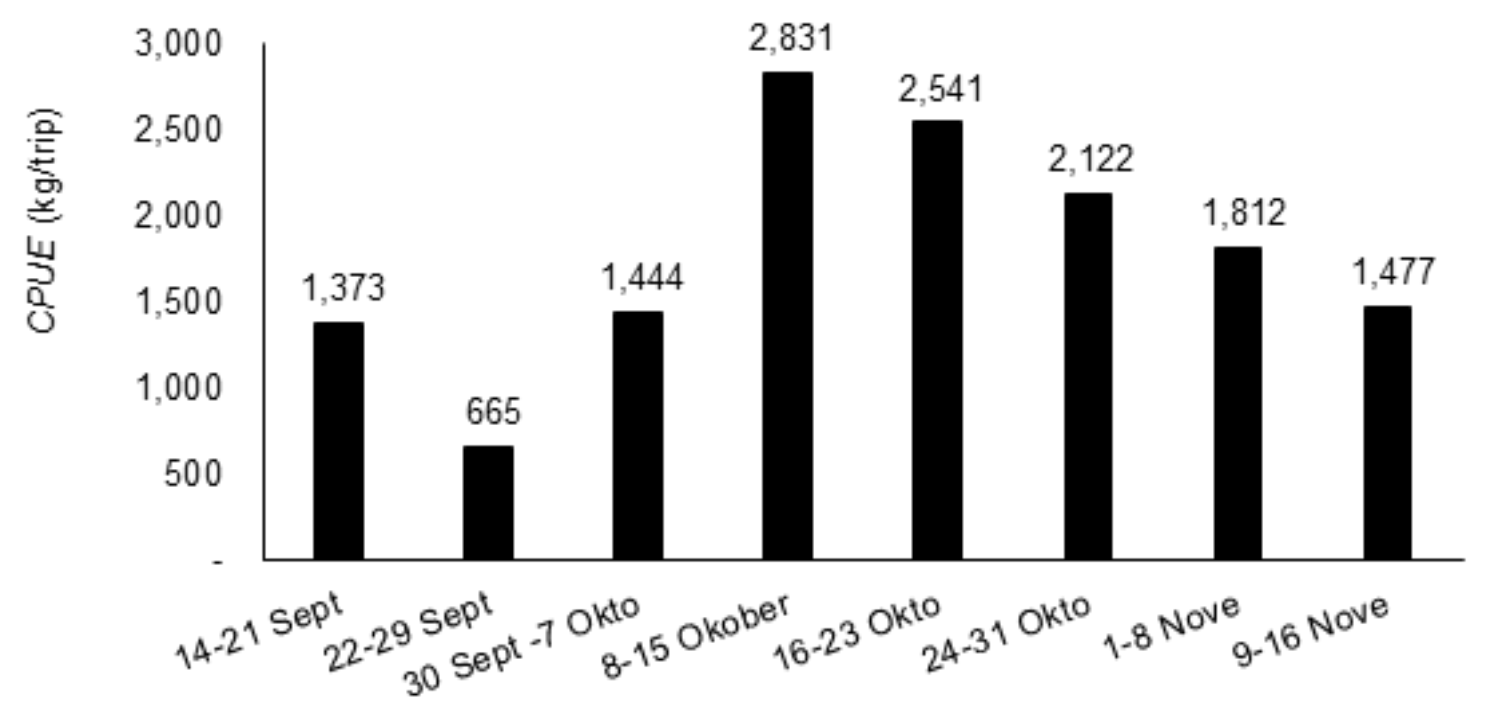

Gambar 5. Grafik CPUE (Catch Per Unit Effort) ikan layang

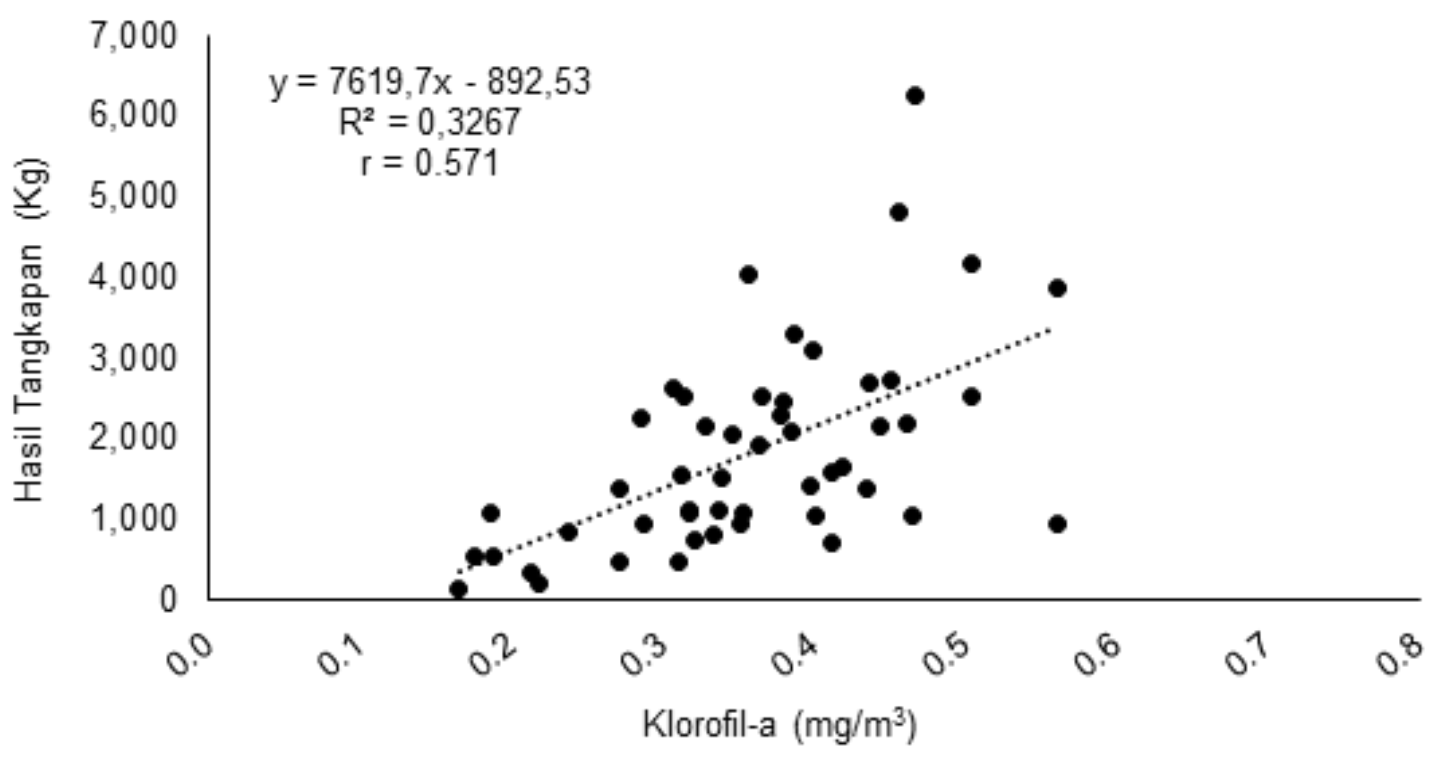

Gambar 6. Grafik pengaruh klorofil-a terhadap hasil tangkapan ikan layang

Menurut Nontji (2005), suhu merupakan salah satu parameter oseanografi yang diduga mempunyai hubungan terhadap kehidupan ikan khususnya dan sumber hayati laut pada umumnya. Sebagian besar biota laut menyukai suhu yang optimum sehingga suhu merupakan salah satu faktor yang sangat penting dalam mengatur proses kehidupan dan penyebaran organisme di perairan (Nybakken 1992).

Gambar 7 menunjukkan pengaruh hasil tangkapan ikan layang terhadap suhu permukaan laut yang bahwa nilai koefisien determinasi $\left(\mathrm{R}^{2}\right)$ sebesar 0,1296. Nilai tersebut menggambarkan bahwa parameter suhu permukaan laut berkontribusi terhadap ikan layang hanya sebesar 12,96\% dan sisanya dipengaruhi oleh faktor lain. Nilai koefisien korelasi (r) sebesar 0,347, kondisi ini menunjukkan adanya korelasi yang cukup dengan arah hubungan bersifat negatif. Grafik pengaruh suhu permukaan laut terhadap hasil tangkapan ikan layang disajikan pada Gambar 7.

Gambar 7 juga menunjukkan bahwa fluktuasi suhu permukaan laut di perairan sekitar Pidie Jaya tidak begitu signifikan dalam menentukan banyak atau tidaknya hasil tangkapan yang diperoleh didaerah tersebut. Ikan layang (Decapterus spp) dalam melakukan ruaya (migrasi) di suatu perairan dengan cara mengikuti kadar garam 
yang bersalinitas tinggi. Menurut Asikin (1971); Andrius (2007); Simbolon (2011) kisaran salinitas yang dapat disenangi oleh ikan layang pada suatu perairan berkisar antara 32 sampai 33,75 \%o.

\section{Ukuran panjang ikan layang}

Ukuran panjang ikan layang yang tertangkap pada bulan September sampai November 2018 berkisar antara 15,5 cm sampai $20,1 \mathrm{~cm}$ dengan panjang rata-rata ikan layang yaitu $18,3 \mathrm{~cm}$ (Gambar 8). Gambar 8 menunjukkan ukuran panjang ikan layang tertinggi tertangkap pada kawasan daerah penangkapan ikan titik E (523'10" LU dan 96 $15^{\prime} 00^{\prime \prime}$ BT) yaitu 20,1 cm dan ukuran panjang ikan layang terkecil tertangkap pada kawasan daerah penangkapan ikan titik A $\left(5^{\circ} 18^{\prime} 50^{\prime \prime}\right.$ LU dan $96^{\circ} 17^{\prime} 40^{\prime \prime}-96^{\circ} 18^{\prime} 11^{\prime \prime}$ BT) yaitu $15,6 \mathrm{~cm}$. Ukuran ikan layang pertama matang gonat atau layak tangkap yaitu diatas $16,1 \mathrm{~cm}$ (Fishbase 2018).

Daerah penangkapan ikan secara keseluruhan dapat dikatakan bahwa lokasi daerah penangkapan ikan layang potensial berada diatas 6 mil laut, sehingga dapat direkomendasikan kepada nelayan Pidie Jaya untuk melakukan kegiatan penangkapan ikan layang. Daerah penangkapan ikan layang yang dibawah 6 mil laut terdapat hasil tangkapan ikan yang masih berukuran kecil atau belum layak tangkap. Jika hal ini terus dilakukan oleh nelayan maka akan dapat mempengaruhi keramahan lingkungan yang dilihat dari segi perbandingan ukuran panjang total (TL) dengan Length at first maturity (Lm).

\section{Pendugaan daerah penangkapan ikan layang}

Fluktuasi hasil tangkapan ikan di suatu daerah penangkapan ikan ditentukan oleh penyediaan kondisi oseanografi yang optimum pada suatu perairan tersebut, yaitu suhu permukaan laut, konsentrasi klorofil-a, salinitas maupun parameter lainnya. Setiap organisme atau biota laut (ikan) akan bergerak untuk mengikuti atau mencari habitat yang sesuai dengan kebutuhan tubuhnya dan disamping itu juga karena adanya faktor makanan. Setiap organisme perairan salah satunya adalah ikan layang akan bergerak mengikuti sebaran kondisi yang sesuai dengan kebutuhan tubuhnya, disamping itu juga karena dalam faktor mencari makanan di perairan.

Berdasarkan hasil scoring terhadap keempat indikator pendugaan daerah penangkapan ikan layang pada 10 lokasi daerah penangkapan di perairam Aceh sekitar Pidie Jaya disajikan pada Tabel 1 . Pendugaan daerah penangkapan ikan layang selama penelitian yaitu bulan September sampai November (musim peralihan TimurBarat) yang terdapat di perairan Aceh sekitar Pidie Jaya diperoleh dua kategori, yaitu daerah penangkapan ikan layang potensial dan daerah penangkapan ikan layang kurang potensial (Tabel 1 dan Gambar 9).

Tabel 1 menunjukkan kategori daerah penangkapan ikan layang potensial dan kategori daerah penangkapan ikan layang kurang potensial. Daerah penangkapan ikan layang potensial terdapat pada lokasi daerah penangkapan ikan titik D, E, F, G, H, I dan J, sedangkan daerah penangkapan ikan layang kurang potensial terdapat pada lokasi A, B, dan C dapat dilihat pada Gambar 9.

Gambar 9 menunjukkan kawasan daerah penangkapan ikan layang potensial dan daerah penangkapan ikan layang kurang potensial di perairan Aceh sekitar Pidie Jaya pada musim peralihan TimurBarat. Kawasan daerah penangkapan ikan layang potensial ditandai dengan warna hijau atau berada pada laut diatas 6 mil laut dari garis pantai, sedangkan daerah penangkapan ikan layang kurang potensial ditandai dengan warna kuning atau pada kawasan A, B, dan C (Gambar 9). 


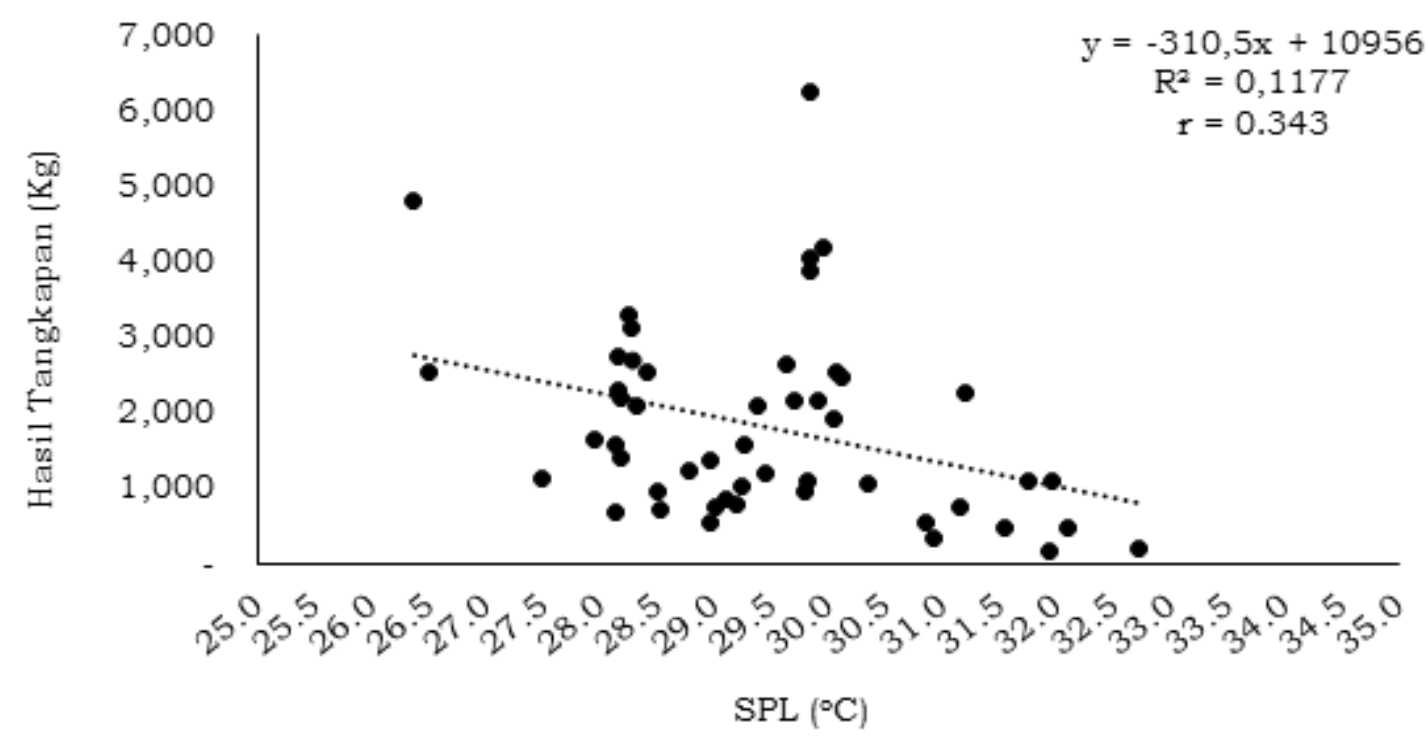

Gambar 7. Grafik pengaruh suhu permukaan laut terhadap hasil tangkapan ikan layang

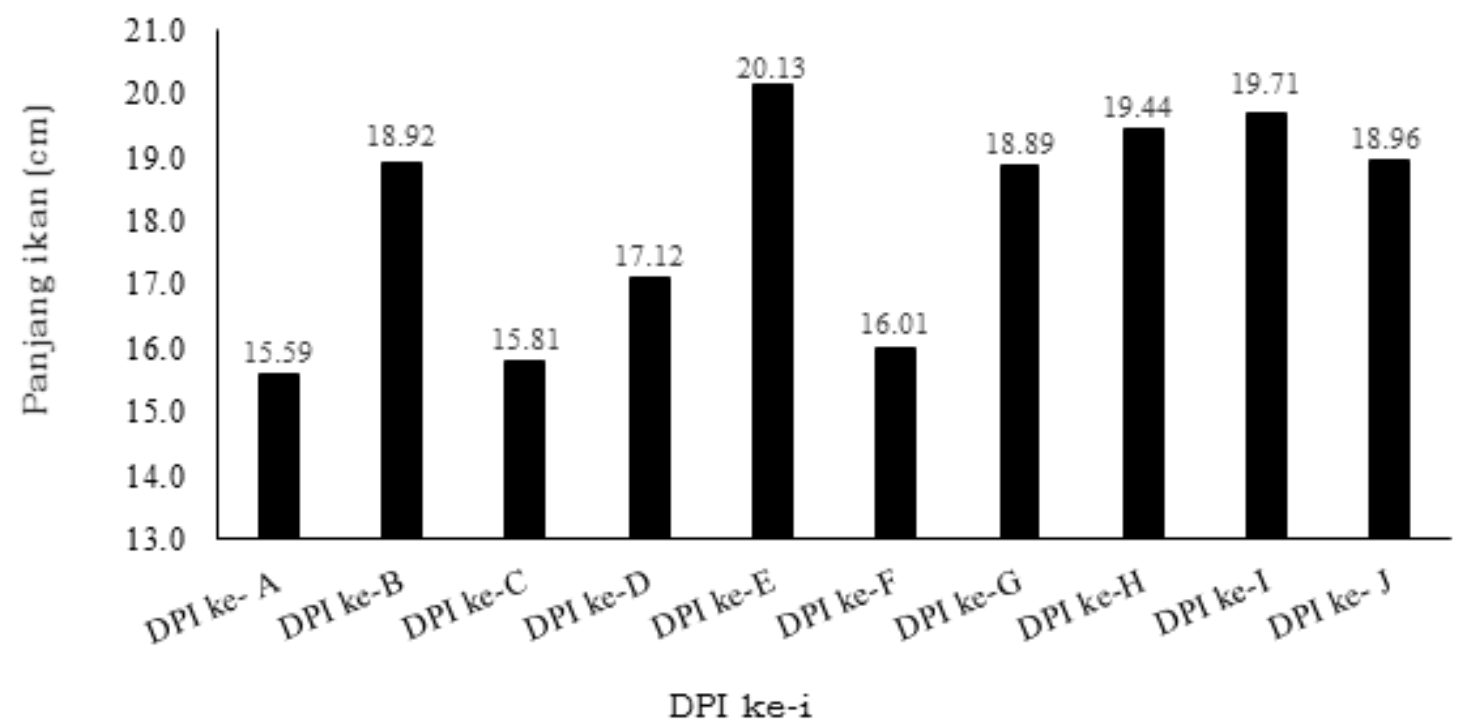

Gambar 8. Ukuran panjang ikan layang

Tabel 1. Kawasan koordinat dan jarak tempuh ke daerah penangkapan ikan layang

\begin{tabular}{|c|c|c|c|c|c|}
\hline Kategori & DPI & Lintang Utara (N) & Bujur Timur (E) & Jarak (Nm) & Luasan (Km) \\
\hline \multirow{7}{*}{ Potensial } & $\mathrm{D}$ & $5^{0} 17^{\prime} 55^{\prime \prime}-5^{0} 19^{\prime} 40^{\prime \prime}$ & $96^{0} 22^{\prime} 10^{\prime \prime}-96^{0} 24^{\prime} 20^{\prime \prime}$ & 3,91 & 4,2 \\
\hline & $\mathrm{E}$ & $5^{0} 21^{\prime} 50^{\prime \prime}-5^{0} 23^{\prime} 00^{\prime \prime}$ & $96^{0} 17^{\prime} 00^{\prime \prime}-96^{\circ} 18^{\prime} 35^{\prime \prime}$ & 8,16 & 5,3 \\
\hline & $\mathrm{G}$ & $5^{0} 22^{\prime} 15^{\prime \prime}-5^{0} 23^{\prime} 40^{\prime \prime}$ & $96^{0} 22{ }^{\prime} 30^{\prime \prime}-96^{0} 23^{\prime} 10^{\prime \prime}$ & 8,05 & 2,6 \\
\hline & $\mathrm{H}$ & $5^{0} 24^{\prime} 10^{\prime \prime}-5^{\circ} 26^{\prime} 20^{\prime \prime}$ & $96^{0} 14^{\prime} 55^{\prime \prime}-96^{0} 17^{\prime} 00^{\prime \prime}$ & 9,82 & 4,0 \\
\hline & $\mathrm{I}$ & $5^{0} 27^{\prime} 40^{\prime \prime}-5^{0} 29^{\prime} 20^{\prime \prime}$ & $96^{0} 19^{\prime} 20^{\prime \prime}-96^{0} 21^{\prime} 30^{\prime \prime}$ & 14,02 & 4,3 \\
\hline & $\mathrm{J}$ & 5032'10”-5033’30" & $96^{0} 23^{\prime} 10^{\prime \prime}-96^{0} 33^{\prime} 30^{\prime \prime}$ & 18,75 & 2,5 \\
\hline & $\mathrm{F}$ & $5^{0} 22^{\prime} 40^{\prime \prime}-5^{0} 24^{\prime} 10^{\prime \prime}$ & $96^{\circ} 14^{\prime} 00^{\prime \prime}-96^{0} 15^{\prime} 40^{\prime \prime}$ & 5,18 & 4,6 \\
\hline \multirow{3}{*}{$\begin{array}{l}\text { Kurang } \\
\text { potensial }\end{array}$} & $\mathrm{A}$ & $5^{0} 17^{\prime} 50^{\prime \prime}-5^{\circ} 18^{\prime} 40^{\prime \prime}$ & $96^{0} 16^{\prime} 20^{\prime \prime}-96^{\circ} 17^{\prime} 40^{\prime \prime}$ & 3,82 & 2,1 \\
\hline & B & $5^{0} 17^{\prime} 40^{\prime \prime}-5^{0} 19^{\prime} 30^{\prime \prime}$ & $96^{0} 18^{\prime} 25^{\prime \prime}-96^{\circ} 20^{\prime} 09^{\prime \prime}$ & 8,34 & 4,0 \\
\hline & $\mathrm{C}$ & $5^{0} 19^{\prime} 57^{\prime \prime}-5^{0} 21^{\prime} 00^{\prime \prime}$ & $96^{\circ} 15^{\prime} 30^{\prime \prime}-96^{\circ} 18^{\prime} 00^{\prime \prime}$ & 8,34 & 5,5 \\
\hline
\end{tabular}




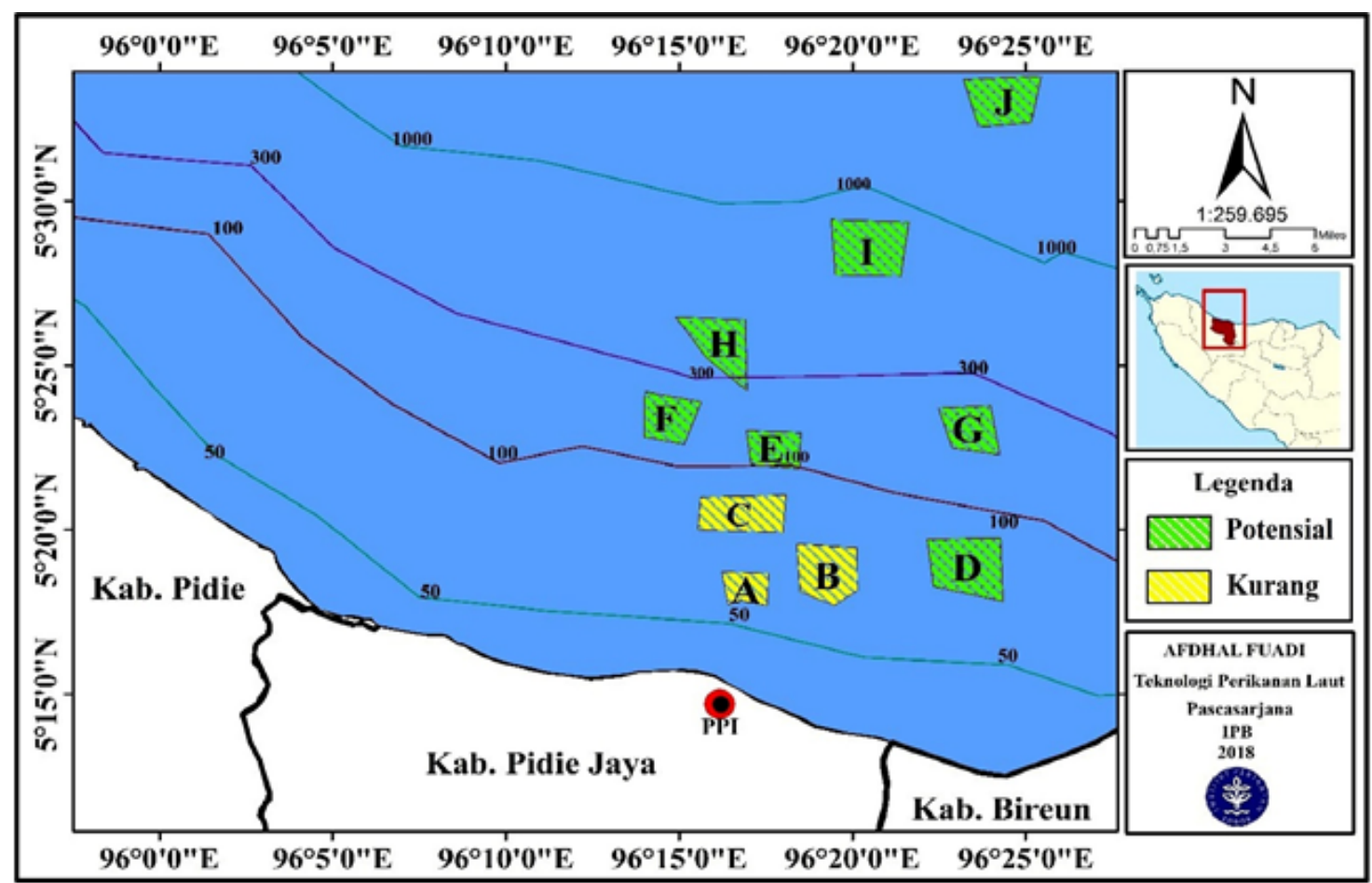

Gambar 9. Peta daerah penangkapan ikan layang di perairan Aceh sekitar Pidie Jaya 2018

\section{KESIMPULAN DAN SARAN}

\section{Kesimpulan}

Berdasarkan hasil penelitian yang dilakukan pada bulan September sampai dengan bulan November 2018 (Musim peralihan Timur-Barat) dapat diambil beberapa kesimpulan sebagai berikut: (1) Hasil tangkapan ikan layang paling banyak tertangkap pada tanggal 8 sampai 15 Oktober sebanyak $19.816 \mathrm{~kg}$ yang terdapat pada suhu kisaran $28,90{ }^{\circ} \mathrm{C}$ dan pada rata-rata konsentrasi klorofil-a 0,27 $\mathrm{mg} / \mathrm{m}^{3}$, (2) Pengaruh klorofil-a terhadap hasil tangkapan ikan layang menunjukkan adanya korelasi yang kuat dengan arah hubungan bersifat positif dengan nilai koefisie korelasi (r) sebesar 0,586\%, sedangkan hubungan suhu permukaan laut terhadap hasil tangkapan ikan layang menunjukkan adanya korelasi yang cukup berpengaruh dengan arah hubungan negatif dengan nilai koefisien korelasi (r) sebesar 0,347\%, (3) Daerah potensial penangkapan ikan layang berada pada laut bagian Utara atau lepas pantai yang berjarak dari fishing base ke fishing ground $>6$ mil laut.

\section{Saran}

Berdasarkan hasil pembahasan di atas tentang pendugaan daerah penangkapan ikan layang yang layak tangkap dapat disarankan beberapa hal sebagai berikut: Diperlukan penelitian selanjutnya untuk kawasan yang lebih luas (Kabupaten Pidie, Pidie Jaya, Bireun, dan Lhoksemawe) untuk mengetahui pergerakan atau migrasi ikan layang di perairan Aceh khususnya untuk wilayah pantai Timur. Kemudian perlu adanya peran pemerintah terhadap nelayan untuk melakukan pemindahan daerah penangkapan ikan yang kurang potensial di sekitar pesisir pantai di bawah 6 mil laut untuk nelayan skala mini purse seine.

\section{DAFTAR PUSTAKA}

Amri K. 2002. Hubungan Kondisi Oseanografi (Suhu Permukaan Laut, Klorofil-a, dan Arus) dengan Hasil Tangkapan Ikan Pelagis Kecil di Perairan Selat Sunda [Tesis]. Bogor: Program Pascasarjana, Institut Pertanian Bogor.

Andrius. 2007. Model Spasial Informasi Daerah Penangkapan Ikan Layang (Decapterus spp) Di Antara Perairan Selat Makasar dan Laut Jawa (11001200 BT - 2050'-7050' LS) [Tesis]. Bogor: Program Pascasarjana, Institut Pertanian Bogor.

Asikin D. 1971. Synopsis Biologi Ikan Layang (Decapterus spp). Jakarta: LPPL. Hlm 
3-27.

Azwar, Saifuddin. 2010. Metode Penelitian. Yogyakarta: Pustaka Pelajar.

Baskoro MS, Wahyu RI, Effendi A. 2004. Migrasi dan Distribusi Ikan. Bogor: Fakultas Perikanan dan Ilmu Kelautan Institut Pertanian Bogor. $152 \mathrm{hlm}$.

Basuma T. 2009. Penentuan Daerah Penangkapan Ikan Tongkol Berdasarkan Suhu Permukaan Laut dan Hasil Tangkapan di Perairan Binuangeun, Banten [Tesis]. Bogor: Institut Pertanian Bogor.

FebriSP.2012.EvaluasiDaerahPenangkapan Ikan Layang (Decapterus Spp) Berdasarkan Indikator Komposisi Hasil Tangkapan, Suhu Permukaan Laut Dan Klorofil-a [Tesis]. Bogor: Institut Pertanian Bogor.

Fishbase. 2018. Perikanan makarel di Selat Malaka. www.fishbase.org. [25 February 2018].

Fuadi A, Musman M, MiswarE. 2016. Validasi Daerah Potensial Penangkapan Ikan Pelagis Kecil Menggunakan Purse Seine dengan citra Satelit di Perairan Pidie Jaya. Jurnal Ilmiah Mahasiswa Kelautan dan Perikanan Unsyiah. 1(2) : 195-202.

Gaol JL, Wudianto BP, Pasaribu D, Manurung, Endriani R. 2004. The Fluctuation of Chlorofill-a Concentration Derived from Satellite Imagery and Catch of Oily Sardine (Sardinella lemuru) in Bali Strait. Journal Remote Sensing and Earth Science. 1(1) : 24-30.

Gower JFR, Apel JR. 1972. Opportunities and Problems in Satellite Measurements of the Sea. UNESCO Tech. Pap. 46. 70 p.

Gulland. 1983. Fish Stock Assesment, A Manual Basic Methods. New York: Pergamon. 223 hlm.

Gunarso W. 1985. Tingkah Laku Ikan dalam Hubungannya dengan Metode dan Teknik Penangkapan. Jurusan Pemanfaatan Sumberdaya Perikanan, Fakultas Perikanan. Institut Pertanian Bogor. 149 hal.

Hamka E. 2012. Pemetaan Daerah Penangkapan Potensial Ikan Layang (Decapterus Spp) di Laut Banda [Tesis]. Bogor: Institut Pertanian Bogor.

Laevastu T, Hayes ML. 1981. Fisheries Oceanography and Ecology. New York: Fishering News (Book).
Laevastu T, Hela. 1980. Fisheries Oceanography New Ocean Environmental Services. London: Fishing News (Book). 238 hal.

Liestina H, Ghofar A, Rudiyanti S. 2015. Aspek Biologi Ikan Layang (Decapterus macrosoma) yang Didaratkan di PPP Sadeng, Gunungkidul, Yogyakarta. http://ejournal-s1.undip.ac.id/index. php/maquares. 4(4) : 10-18.

Mugo R, Saitoh S, Nihira A, Kuroyama T. 2010. Habitat Characteristics of Skipjack Tuna (Katsuwonus pelamis) in the Western North Pacific: a Remote Sensing Perspective. Journal of Fisheries Oceanography. (19) : 382396.

Muklis, GaolJL, Simbolon D. 2009. Pemetaan Daerah Potensial Penangkapan Ikan, Cakalang, Tongkol, Perairan Utara Nanggroe Aceh Darussalam. E-Jurnal Ilmu dan Teknologi Kelautan Tropis. 1(1) : 24-32.

Nontji A. 2005. Laut Nusantara. Jakarta: Penerbit Sjambatan. 372 hal.

Nybakken J. 1992. Biologi Laut Suatu Pendekatan Ekologis. Jakarta: PT. Gramedian. 459 hal.

Parson TR, Takahasshi M, Hargrave B. 1984. Biological Oceanographic Processes. England: Pergamon Press. 330 hal.

Polovina JJ, Howel E, Kobayashi DR, Seki MP. 2001. The Transition Zone Chlorophyll Front, A Dynamic Global Feature Defining Migration and Forage Habitat for Marine Resources. Journal Progress in Oceanography. 4(9) : 469-483.

Prastianto F. 2016. Analisis dan Pemetaan Konsentrasi Klorofil-a di Selat Makassar sebagai Acuan untuk Pembuatan Peta Prakiraan Daerah Penangkapan Ikan dengan Menggunakan Citra Satelit AquaMODIS. Jurnal Ilmu Perikanan Tropis. 21(2) : 24-31.

Petrere JM, Giacomini HC, De Marco JP. 2010. Catch-per-unit-effort: which Estimator is Best. Braz J Biol. 70 : 483-491.

Rahmawati M, Fitri ADP, Wijayanto D. 2013. Analisis Hasil Tangkapan Per Upaya Penangkapan dan Pola Musim Penangkapan Ikan Teri (Stolephorus Spp.) di Perairan Pemalang. Journal of Fisheries Resources Utilization Management and Technology. 2(3) : 213-222.

Rizwan, Ichsan S, Aprilla RM. 2011. Effect 
of Production Factors on Purse Seine Fish Capture in the Lampulo Coastal Fisheries Port, Banda Aceh. Jurnal Natural. 11(1) : 24-29.

Royce WF. 1984. Introduction to The Practice of Fishery Science. College of Ocean and Fishery Sciences. University of Washington Academic Press. 428 hal.

Safruddin. 2013. Distribusi Ikan Layang (Decapterus spp) Hubungannya dengan Kondisi Oseanografi di Perairan Kabupaten Pangkep, Sulawesi Selatan. Torani (Jurnal Ilmu Kelautan dan Perikanan). 23(3) : 150156.

Sarumaha H, Kurnia R, Setyobudiandi. 2016. Biologi Reproduksi Ikan Kuniran Upeneus moluccensis Bleeker, di Perairan Selat Sunda. Jurnal Ilmu dan Teknologi Kelautan Tropis. 8(2) : 701-711.

Sarwono J. 2008. Panduan Lengkap untuk Belajar Komputasi Statistik Menggunakan SPSS 16. CV. Andi Offset. Yogyakarta.

Semedi B, Dimyati RD. 2009. Study of Short Mackerel Catch, Sea Surface Temperature, and Chlorophyl-a in the Makassar Strait. Internasional Jurnal of Remote Sensing and Earth Sciences. $6: 77-84$.

Simbolon D, Irnawati R, Sitanggang LP, Ernaningsih D, Tadjuddah M. 2009. Pembentukan Daerah Penangkapan Ikan. Penerbit: Departemen Pemanfaatan Sumber daya Perikanan. Fakultas Perikanan dan Ilmu Kelautan. Institut Pertanian Bogor.

Simbolon D. 2011. Bioekologi dan Dinamika
Penangkapan Daerah Penangkapan Ikan. Cetakan Pertama. Penerbit Departemen Pemanfaatan Sumber daya Perikanan. Fakultas Perikanan dan Ilmu Kelautan, Institut Pertanian Bogor. 221 hlm.

Suhartono, Haruna, Paillin JB. 2013. Identifikasi dan Prediksi Daerah Penangkapan Ikan Kembung (Rastrelliger spp) di Perairan Kabupaten Pangkep. Jurnal "Amanisal" PSP FPIK Unpatti-Ambon. 2(2) : 55-65.

Tangke U, Karuwal JWC, Mallawa A, Zainuddin M. 2016. Analisis Parameter Oseanografi Hubungannya dengan Hasil Tangkapan Ikan Tuna Sirip Kuning di Perairan Maluku Utara. Jurnal "Amanisal" PSP FPIK Unpatti-Ambon. 5(1) : 1-9.

Walpole RE. 1995. Pengantar Statistika. Diterjemahkkan oleh Bambang Sumantri: PT. Gramedia Pustaka Utama. Jakarta.

Zainuddin M, Kiyofuji H, Saitoh K, Saitoh S. 2006. Using Multi-sensor Satellite Remote Sensing and Catch Data to Detect Ocean Hot Spots for Albacore (Thunnus alalunga) in the Northwestern North Pacific. Journal Deep-Sea Research. 2(53) : 419-431.

Zainuddin M, Safruddin, Farhum SA, Nelwan A, Selamat MB, Hidayat S, Sudirman. 2015. Karakteristik Daerah Potensial Penangkapan Ikan Cakalang di Teluk Bone-Laut Flores Berdasarkan Data Satelit Suhu Permukaan Laut dan Klorofil-a pada Periode Januari sampai Juni 2014. Jurnal IPTEKS PSP. 2(3) : 228-237. 